\title{
Sodium corrosion resistance of translucent alumina: effect of additives and sintering conditions
}

\section{Citation for published version (APA):}

With, de, G., Vrugt, P. J., \& Ven, van de, A. J. C. (1985). Sodium corrosion resistance of translucent alumina: effect of additives and sintering conditions. Journal of Materials Science, 20(4), 1215-1221.

https://doi.org/10.1007/BF01026317

DOI:

10.1007/BF01026317

Document status and date:

Published: 01/01/1985

\section{Document Version:}

Publisher's PDF, also known as Version of Record (includes final page, issue and volume numbers)

\section{Please check the document version of this publication:}

- A submitted manuscript is the version of the article upon submission and before peer-review. There can be important differences between the submitted version and the official published version of record. People interested in the research are advised to contact the author for the final version of the publication, or visit the $\mathrm{DOI}$ to the publisher's website.

- The final author version and the galley proof are versions of the publication after peer review.

- The final published version features the final layout of the paper including the volume, issue and page numbers.

Link to publication

\section{General rights}

Copyright and moral rights for the publications made accessible in the public portal are retained by the authors and/or other copyright owners and it is a condition of accessing publications that users recognise and abide by the legal requirements associated with these rights.

- Users may download and print one copy of any publication from the public portal for the purpose of private study or research.

- You may not further distribute the material or use it for any profit-making activity or commercial gain

- You may freely distribute the URL identifying the publication in the public portal.

If the publication is distributed under the terms of Article 25fa of the Dutch Copyright Act, indicated by the "Taverne" license above, please follow below link for the End User Agreement:

www.tue.nl/taverne

Take down policy

If you believe that this document breaches copyright please contact us at:

openaccess@tue.nl

providing details and we will investigate your claim. 


\title{
Sodium corrosion resistance of translucent alumina: effect of additives and sintering conditions
}

\author{
G. DE WITH, P.J.VRUGT*, A. J.C. VAN DE VEN \\ Philips Research Laboratories, P.O.B. 80.000,5600 JA Eindhoven, The Netherlands
}

The resistance of $\mathrm{Al}_{2} \mathrm{O}_{3}$ against corrosion by sodium in the temperature range 800 to $1000^{\circ} \mathrm{C}$ was studied by holding samples in liquid sodium in molybdenum containers for several hundred hours. Thermodynamic calculations indicating that $\mathrm{Al}_{2} \mathrm{O}_{3}$ is unstable in contact with sodium were confirmed by testing sapphire samples. A remarkable aspect was the large anisotropy in the corrosion resistance of sapphire. The effect of the sintering atmosphere and the amount of $\mathrm{MgO}$ and $\mathrm{CaO}$ dopant in polycrystalline alumina on the corrosion resistance was considered. Vacuum sintering yielded more resistant materials than hydrogen sintering. Low firing temperatures as well as low dopant levels also proved beneficial. In particular, the absence of $\mathrm{CaO}$ improves the corrosion resistance considerably. Consequently, the use of this additive should be avoided.

\section{Introduction}

Alumina is a common arc tube material for highpressure sodium discharge lamps. Operating temperatures typically range from about $750^{\circ} \mathrm{C}$ at the ends of the tube to about $1250^{\circ} \mathrm{C}$ in the middle. Important properties are translucency, strength and chemical inertness. The addition of a few hundred ppm of dopant, usually $\mathrm{MgO}$, is required for proper sintering to translucency. A further improvement in translucency can be obtained by adding an additional amount of $\mathrm{CaO}$ ([1], see also [2]) usually a few tenths wt ppm. It is known, however, that $\mathrm{CaO}$ segregates heavily on the grain boundaries of polycrystalline alumina [3]. This segregation possibly influences the corrosion of alumina by sodium. Furthermore, an influence of the sintering atmosphere on the corrosion resistance can be expected. A detailed picture of the corrosion phenomena is not yet available in spite of several investigations [4-6]. All these investigations were done with burning lamps. The condi. tions in these lamps are rather complicated, but the experiments do indicate that the addition of $\mathrm{CaO}$ has a detrimental influence. In order to obtain more insight, corrosion experiments were done on small alumina blocks encapsulated in a molybdenum box and heated in contact with sodium for several hundred hours at elevated temperature.

\section{Sodium attack}

When studying the stability of alumina in contact with sodium, inter-oxide compound formation should be taken into account. The following sodium-aluminates have been described in the literature $[7,8]$ :

$\mathrm{N}_{5} \mathrm{~A}, \mathrm{NA}, \mathrm{NA}_{5-7}\left(\beta^{\prime \prime}\right.$-alumina $), \mathrm{NA}_{9-11}(\beta$-alumina $)$

in which

$$
\mathrm{N}_{x} \mathrm{~A}_{y}=x \mathrm{Na}_{2} \mathrm{O} \cdot y \mathrm{Al}_{2} \mathrm{O}_{3} .
$$

Thermodynamic data for NA and $\beta$-alumina are given in the literature $\dagger$. These substances can be formed by reactions between liquid sodium or saturated sodium vapour and $\mathrm{Al}_{2} \mathrm{O}_{3}$ according to:

$$
\begin{array}{r}
3 \mathrm{Na}+2 \mathrm{Al}_{2} \mathrm{O}_{3} \rightarrow \frac{3}{2} \mathrm{NA}+\mathrm{Al}+\Delta G_{1} \\
\frac{6}{17} \mathrm{Na}+2 \mathrm{Al}_{2} \mathrm{O}_{3} \rightarrow \frac{3}{17} \mathrm{NA}_{11}+\frac{2}{17} \mathrm{Al}+\Delta G_{11} .
\end{array}
$$

*Present address: Nederlandse Philips Bedrijven B.V. Lighting Division, 5600 MD Eindhoven, The Netherlands.

$\dagger$ All thermodynamic data were taken from references [9-11]. 
TAB LE I Material characteristics

\begin{tabular}{lllllll}
\hline Material & Sintering & $\begin{array}{l}\text { MgO } \\
(\text { wt ppm })\end{array}$ & $\begin{array}{l}\mathrm{CaO} \\
(\text { wt ppm })\end{array}$ & $\rho(\%)$ & $\begin{array}{l}D_{50} \\
(\mu \mathrm{m})\end{array}$ & $\ln \left(\frac{D_{50}}{D_{16}}\right)$ \\
\hline 1 & Vac, $1850^{\circ} \mathrm{C}-8 \mathrm{~h}$ & 100 & 2 & 99.94 & 19 & 0.52 \\
2 & $\mathrm{Vac}, 1850^{\circ} \mathrm{C}-8 \mathrm{~h}$ & 100 & 6 & 99.89 & 26 & 0.47 \\
3 & $\mathrm{Vac}, 1850^{\circ} \mathrm{C}-8 \mathrm{~h}$ & 100 & 16 & 99.91 & 13 & 0.55 \\
4 & $\mathrm{Vac}, 1850^{\circ} \mathrm{C}-8 \mathrm{~h}$ & 100 & 41 & 99.92 & 18 & 0.78 \\
5 & $\mathrm{H}_{2}, 1670^{\circ} \mathrm{C}-8 \mathrm{~h}$ & 100 & 2 & 99.71 & 11 & 0.37 \\
6 & $\mathrm{H}_{2}, 1670^{\circ} \mathrm{C}-8 \mathrm{~h}$ & 300 & 2 & 99.63 & 15 & 0.56 \\
7 & $\mathrm{H}_{2}, 1825^{\circ} \mathrm{C}-8 \mathrm{~h}$ & 100 & 2 & 99.65 & 5 & 0.99 \\
8 & $\mathrm{H}_{2}, 1825^{\circ} \mathrm{C}-8 \mathrm{~h}$ & 300 & 2 & 99.65 & 2 & 0.62 \\
\hline
\end{tabular}

$*$ Vac $=$ vacuum $10^{-5}$ torr.

$\mathrm{H}_{2}=$ moist $\mathrm{H}_{2}$ (dewpoint $\sim 15^{\circ} \mathrm{C}$ ).

In all cases a holding time of $1 \mathrm{~h}$ at $1500^{\circ} \mathrm{C}$ precedes the final sintering step.

The theoretical density is assumed to be $3.986 \mathrm{~g} \mathrm{~cm}^{-3}[13]$.

For other symbols see text.

The free energy change $\dagger, \Delta G_{1}$, is about -3.3 and $-2.7 \mathrm{kcal}$ at 900 and $1000^{\circ} \mathrm{C}$, respectively. For the second reaction, $\Delta G_{11}$ is approximately constant at $-1.8 \mathrm{kcal}$. In principle, therefore, alumina is not stable in the presence of sodium.

\section{Experimental techniques}

\subsection{Preparation and characterization}

The materials were prepared using a commercially available starting powder $\$$. Details of the powder and preparation of the ceramics are given by de With [12]. Materials 1 to $4 \S$ were sintered in vacuum $\left(10^{-5}\right.$ torr $)$ using the minimum amount of about $100 \mathrm{wt} \mathrm{ppm} \mathrm{MgO}$ necessary to obtain a dense, translucent ceramic [13] meanwhile varying the $\mathrm{CaO}$ content. For materials 5 and 7 this minimum amount was used again but now sintered in moist hydrogen (dewpoint $15^{\circ} \mathrm{C}$ ) at a relatively low and high temperature, respectively. Finally, materials 6 and 8 were also fired in hydrogen at these two temperatures, but now with the $300 \mathrm{wt}$ ppm MgO. Further details are given in Table I.

After polishing and etching (see [12]) the area distribution of the grains was determined. From these data the volume grain size number distributions were calculated by means of the SaltikowJohnson transformation [14]. The density was determined using Prokic's method [15].

\subsection{Corrosion experiments}

The kinetics of the reactions between alumina and sodium were studied by loading a molybdenum cup with alumina (either a block or an amount of powder) and an overdose of sodium. All samples were taken from the bulk of relatively large sintered blocks to avoid sinter skin-effects. The molybdenum was outgassed in a vacuum of about $10^{-5}$ torr for $1 \mathrm{~h}$ at $1000^{\circ} \mathrm{C}$. The test samples $(10$ to $30 \mathrm{~mm}^{3}$ ) were cleaned for $5 \mathrm{~min}$ at $50^{\circ} \mathrm{C}$ in diluted (1:1 vol parts) $\mathrm{HNO}_{3}$, rinsed in demi-water, and dried in air. Before entering the molybdenum cup both the bulk pieces and the powders (grain size 45 to $90 \mu \mathrm{m}$ ) were fired in air for $1 \mathrm{~h}$ at $1000^{\circ} \mathrm{C}$. After this pretreatment the sample was placed in the molybdenum cup, 20 to $50 \mathrm{mg}$ sodium was added under argon atmosphere $\left(P_{\mathrm{O}_{2}} \sim 10^{-3}\right.$ torr $)$ and the cup was sealed by welding. Heating to experimental conditions was performed in an electrically heated tube furnace, operating under a mixture of $75 \% \mathrm{~N}_{2}$ and $25 \% \mathrm{H}_{2}$. The temperature of the cup was determined and controlled within $5^{\circ} \mathrm{C}$. Experiments were performed at 900 and $1000^{\circ} \mathrm{C}$. Holding times were 300 and $100 \mathrm{~h}$, respectively. After the heat treatment the cup was opened in air, and the sample was immediately immersed in petroleum awaiting further sample preparation.

In the case of solid pieces, the test sample was cross-sectioned and polished under petroleum in order to avoid aqueous corrosion during preparation. The samples were examined for possible corrosion products in a scanning electron microscope (SEM) using energy dispersive analysis of $\mathrm{X}$-rays (EDAX) and electron probe microanalysis (EPMA). The experiments with the powders were primarily meant to identify the reaction products

$\dagger$ All thermodynamic data were taken from references [9-11].

+ Ugine Kuhlman, A15Z.

$\S$ Throughout this paper the materials are indicated by their number in Table I. 
using X-ray diffraction analyses. For comparison similar tests were also done on Verneuil-grown sappire. 1

\section{Results and discussion: material characteristics}

The material characteristics are given in Table I. It is clear that the density, $\rho$, is essentially constant and near to the theoretical density, although somewhat lower densities are obtained for materials 5 to 8 , sintered in hydrogen. From previous experiments [12] with samples taken from the bulk of the material, it is known that no $\mathrm{CaO}$ and only $8 \% \mathrm{MgO}$ is lost during vacuum sintering. For hydrogen sintering the loss is presumably less.

The mean grain size, $D_{50}$, ranges from 5 to $26 \mu \mathrm{m}$ and thus is not constant. Furthermore the width of the distribution $\sigma=\ln \left(D_{50} / D_{16}\right)$ is not constant either. Two more remarks can be made. First, it should be noted that the parameters $D_{50}$ and $\sigma$ only give an overall description of the grainsize distribution since some materials showed a tendency towards a bimodal distribution (see also [12]). Second, it would be a difficult if not impossible task to keep these parameters really constant while changing other parameters. In the interpretation of data, one should be aware of this fact.

Finally, we note that there is no agreement about the benefits of $\mathrm{CaO}$ addition on the translucency. Although the original patent [1] and de With [12] claim an increase in transmittance, Peelen [13] did not observe this effect.

\section{Results and discussion: corrosion experiments}

\subsection{Sapphire}

The intrinsic stability of alumina in the presence of sodium was studied using sapphire as test samples. Samples were exposed to the following experimental conditions: $800^{\circ} \mathrm{C} / 500 \mathrm{~h}, 900^{\circ} \mathrm{C} /$ $300 \mathrm{~h}$ and $1000^{\circ} \mathrm{C} / 100 \mathrm{~h}$, respectively in contact with sodium. Basal plane sections (indices 0001 ) as well as prism-like sections (indices $1 \overline{1} 00$ ) were investigated. The surfaces were polished, but sawn and fracture surfaces were also used for the prismlike planes.

The experiments clearly showed that alumina is indeed unstable in all three experimental conditions considered, as indicated by the thermodynamic calculations. The rate of the corrosion reaction, however, proved to be highly dependent upon crystal orientation at the surface and, of course, upon temperature. In all three conditions of temperature and time considered, the basal plane showed very little, if any, corrosion. In contrast, the prism-like planes clearly became corroded. At $800^{\circ} \mathrm{C}$ the corrosion was limited to the outer $5 \mu \mathrm{m}$ after $500 \mathrm{~h}$. With rising temperature, corrosion at this plane increased from about $150 \mu \mathrm{m}$ in $300 \mathrm{~h}$ at $900^{\circ} \mathrm{C}$ to about $180 \mu \mathrm{m}$ in $100 \mathrm{~h}$ at $1000^{\circ} \mathrm{C}$. The sawn and fracture surfaces yielded very similar penetration depths. The results for the $1000^{\circ} \mathrm{C} / 100 \mathrm{~h}$ treatment are shown in Fig. 1.

The X-ray diffraction diagram of sapphire powder heated for $10 \mathrm{~h}$ in contact with sodium only showed peaks that could be attributed to either $\alpha$-alumina or NA. None of the peaks representative of other aluminates could be detected. That the reaction product is indeed NA, and NA only, was confirmed by line scans in the corroded areas using EPMA. No indication was found that the reaction product consisted of more than one phase, whereas the $\mathrm{Al}$ concentration in the corroded layer closely resembled that of NA, using alumina as a reference.

The large difference in corrosion rate noted between different crystal faces indicates that stability of alumina in the presence of pure sodium is a matter of kinetics rather than of thermodynamics. The fact, however, that the reaction proceeds in a given direction within the crystal, the reaction product being $\mathrm{NA}$, proves that $\Delta G_{1}$ is negative, as predicted by Equation 1. According to Equation 2, $\beta$-alumina could be formed thermodynamically, as well, but no indication was found that it actually did at these temperatures.

From these experiments it is concluded that in the temperature range considered, formation of NA at prism-like planes is the main corrosion phenomenon when single-crystalline alumina is brought into contact with sodium.

\subsection{Translucent alumina: effect of $\mathrm{CaO}$ dope}

A sample of material 1 (100 wt ppm $\mathrm{MgO}, 2 \mathrm{wt}$ ppm $\mathrm{CaO}$ ) was heated for $300 \mathrm{~h}$ at $900^{\circ} \mathrm{C}$ in contact with sodium (Fig. $2 \mathrm{a}$ ), and the resulting corrosion was compared with that of sapphire after the same treatment (Fig. 1a). This polycrystalline sample did not show any detectable corrosion, whereas the prism-plane of the single crystal clearly became corroded in the same experimental

IIndustrie de Pierres Scientifiques Hrand Djevahirdjian S.A. CH-1870, Monthey, Switzerland. 

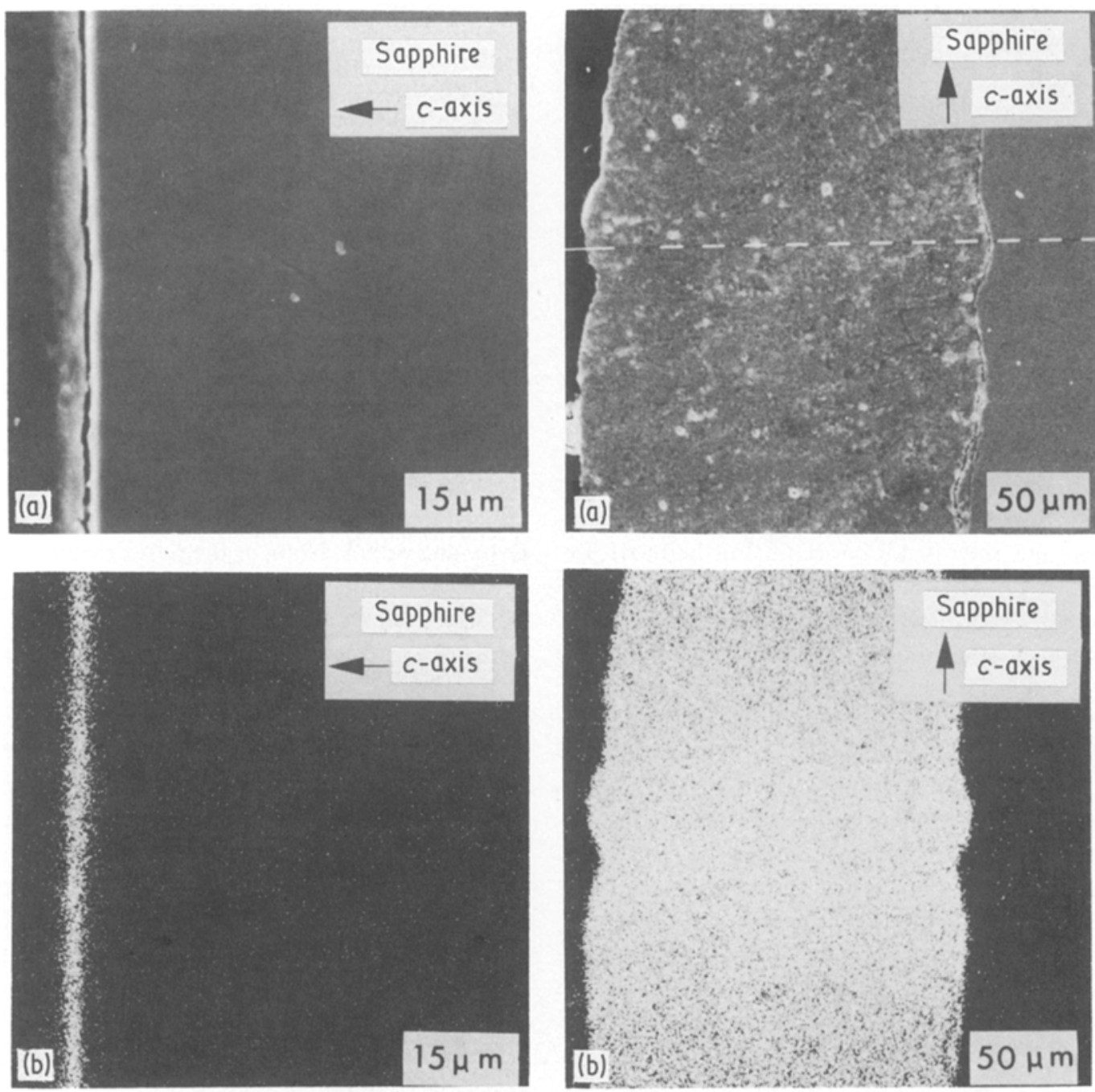

Figure 1 Corrosion of a sapphire sample after $10 \mathrm{~h}$ at $1000^{\circ}$ image (left $\perp c$-axis, right $\| c$-axis).

conditions. Apparently the corrosion resistance of this sintered sample is not adversely affected by the presence of grain boundaries, nor by the 100 wt ppm $\mathrm{MgO}$ added. Raising the temperature to $1000^{\circ} \mathrm{C}$, however, resulted in extreme corrosion after $100 \mathrm{~h}$ (Fig. 2b). Within $100 \mathrm{~h}$ all sodium added ( $1 \mathrm{~mol} \mathrm{Na}$ per mol $\left.\mathrm{Al}_{2} \mathrm{O}_{3}\right)$ did react with the sample, causing the outer part $(\sim 0.5 \mathrm{~mm})$ of the sample to disintegrate completely, the reaction product being NA. In fact the corrosion rate far exceeded that at the prism plane of sapphire after the same treatment. No indication was found that this accelerated corrosion was due to the presence of grain boundaries. Corrosion proceeded front-wise and no preferential corrosion along grain boundaries could be detected. These experi-
C. (a) Electron image (left $\perp c$-axis, right $\| c$-axis) (b) $\mathrm{NaK} \alpha$ ments were repeated with a sample of material 2 differing from material 1 in its $\mathrm{CaO}$ content (6 wt ppm instead of 2). The results were analogous, indicating that such small amounts of $\mathrm{CaO}$ do not significantly affect the stability of the grain boundaries.

Raising the $\mathrm{CaO}$ content further to $16 \mathrm{wt} \mathrm{ppm}$ (material 3) resulted in serious corrosion after $300 \mathrm{~h}$ at $900^{\circ} \mathrm{C}$ in contact with sodium. Corrosion was clearly initiated at the grain boundaries. Sodium could be detected at the grain boundaries to a depth of at least $150 \mu \mathrm{m}$ below the surface. Bulk corrosion was limited to the outer grain(s) (about $30 \mu \mathrm{m}$ ). Increasing the $\mathrm{CaO}$ content to $41 \mathrm{wt}$ ppm resulted in even worse corrosion at $900^{\circ} \mathrm{C}$. Grainboundary corrosion extended at least to $1000 \mu \mathrm{m}$ 

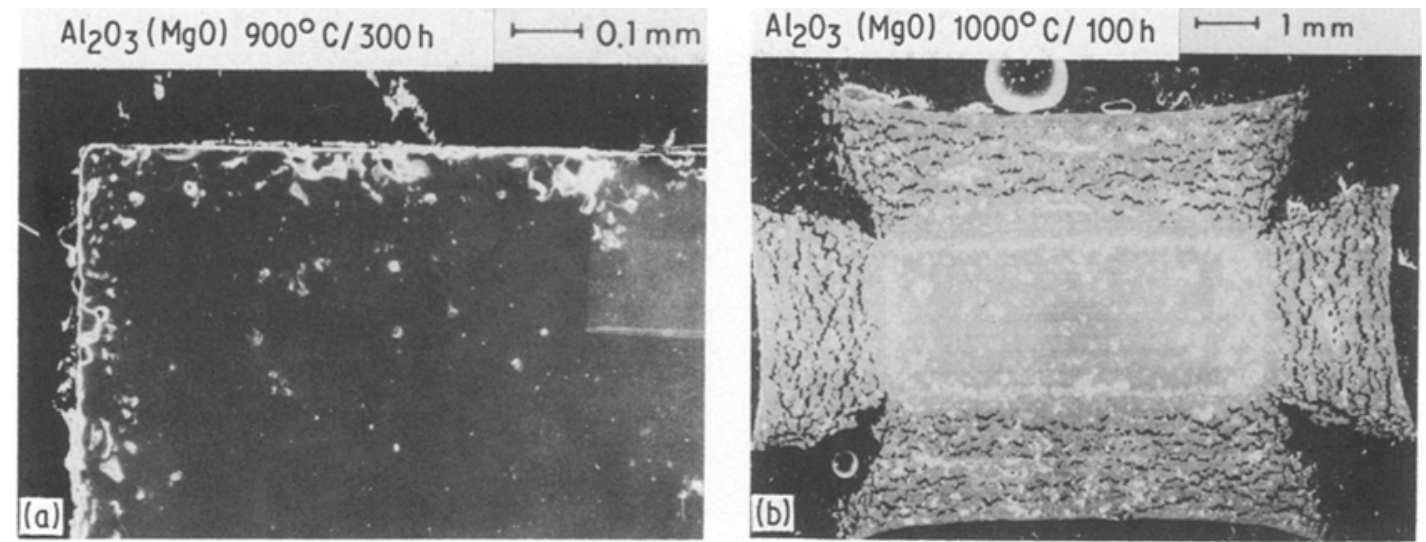

Figure 2 Corrosion of an alumina sample containing $100 \mathrm{wt}$ ppm $\mathrm{MgO}$ and 2 wt ppm $\mathrm{CaO}$ (material 1 ) fired in vacuum $\left(\sim 10^{-5}\right.$ torr): Electron images after (a) $300 \mathrm{~h}$ at $900^{\circ} \mathrm{C}$, and (b) $100 \mathrm{~h}$ at $1000^{\circ} \mathrm{C}$.

below the surface, whereas the outer $100 \mu \mathrm{m}$ of the sample was completely converted into NA (Fig. 3). The excessive corrosion noted at $1000^{\circ} \mathrm{C}$ in the case of samples 1 and 2 was also found with samples 3 and 4.

From these experiments it can be concluded that segregation of $\mathrm{CaO}$ at grain boundaries seriously decreases the stability of these boundaries against penetration of sodium at $900^{\circ} \mathrm{C}$. Although there is no conclusive evidence, the presence of $\mathrm{CaO}$ at the grain boundaries probably leads to the formation of $\mathrm{CaO} \cdot 6 \mathrm{Al}_{2} \mathrm{O}_{3}\left(\mathrm{CA}_{6}\right)$. If it does, the resistance of the grain boundaries against penetration of sodium clearly depends upon the stability of this compound against attack by sodium.

From a thermodynamic point of view $\mathrm{CA}_{6}$ is about as stable as $\mathrm{Al}_{2} \mathrm{O}_{3}$ itself. The free energy change for the reaction:

$$
\begin{gathered}
3 \mathrm{Na}+\frac{2}{5} \mathrm{CA}_{6} \rightarrow \frac{2}{15} \mathrm{C}_{3} \mathrm{~N}_{2} \mathrm{~A}_{5}+\frac{37}{30} \mathrm{NA}+\mathrm{Al} \\
\mathrm{C}=\mathrm{CaO}, \mathrm{N}=\mathrm{Na}_{2} \mathrm{O}, \mathrm{A}=\mathrm{Al}_{2} \mathrm{O}_{3},
\end{gathered}
$$

at $800-1000^{\circ} \mathrm{C}$ is about $-4.5 \mathrm{kcal}$, approximately equal to $\Delta G$ for Reaction 1 . The presence of $\mathrm{CA}_{6}$ at the grain boundaries evidently does not decrease the chemical stability of the alumina. There is, however, a large structural similarity between $\mathrm{CA}_{6}$ and $\beta$-alumina. The high mobility of sodium ions in this latter material is well known. A more efficient initiation of Reaction 1 in the presence of $\mathrm{CA}_{6}$ is thus conceivable.*

The fact that corrosion in the calcia-doped samples is not limited to the grain boundaries, but
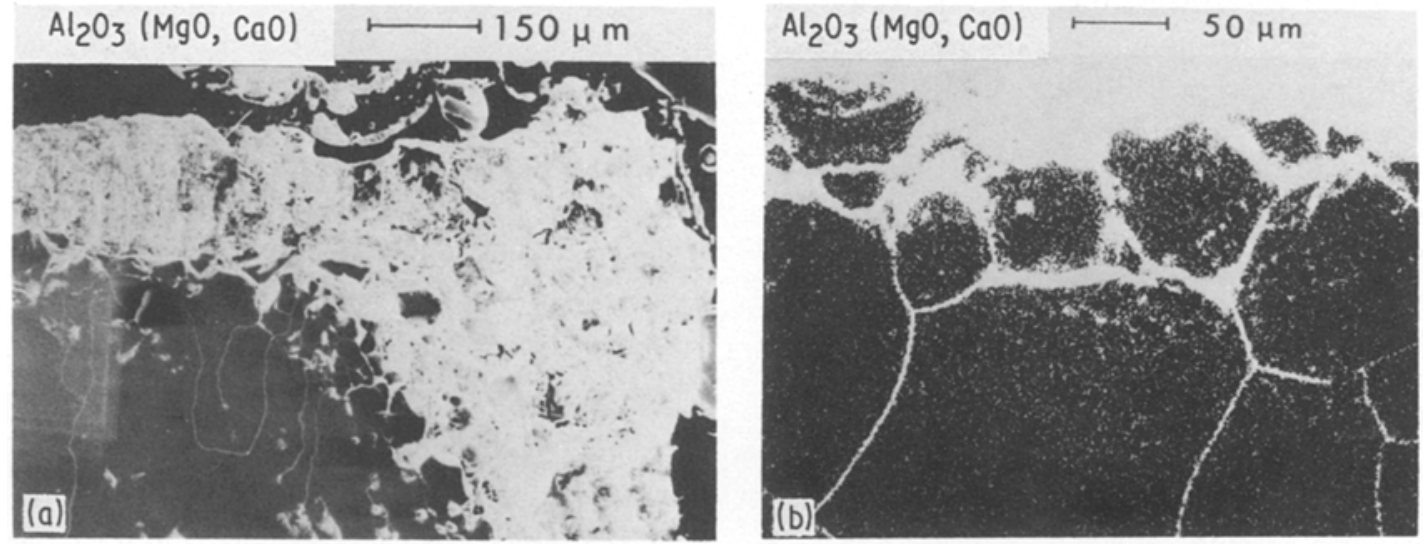

Figure 3 Corrosion of an alumina sample containing $100 \mathrm{wt}$ ppm $\mathrm{MgO}$ and $42 \mathrm{wt} \mathrm{ppm} \mathrm{CaO}$ (material 4) fired in vacuum ( $\sim 10^{-5}$ torr) after $300 \mathrm{~h}$ at $900^{\circ} \mathrm{C}$. (a) Electron image, (b) $\mathrm{NaK} \alpha$ image.

*In fact, sodium cotrosion experiments on $\mathrm{CA}_{6}$ showed that the rate of attack is much larger than for $\mathrm{Al}_{2} \mathrm{O}_{3}$, although again preferentially the grain boundaries are attacked. 

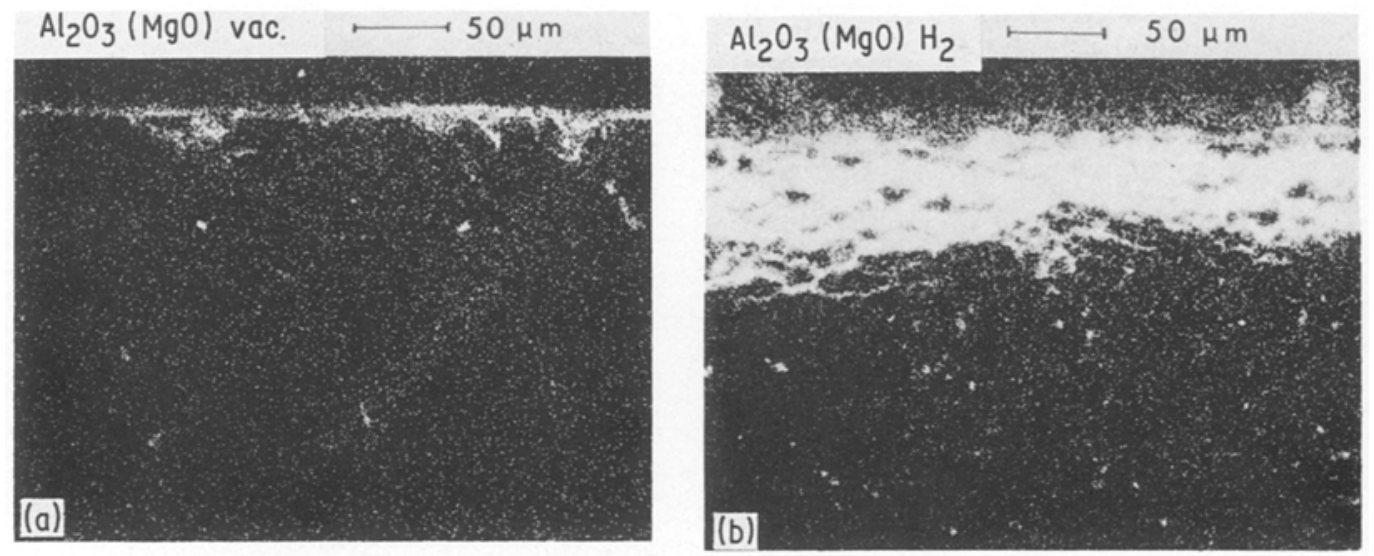

Figure 4 Corrosion of an alumina sample containing $100 \mathrm{wt}$ ppm $\mathrm{MgO}$ and 2 wt ppm $\mathrm{CaO}$ after $300 \mathrm{~h}$ at $900^{\circ} \mathrm{C}(\mathrm{NaK} \alpha$ image). (a) Fired in vacuum $\left(\sim 10^{5}\right.$ torr, material 1$)$. (b) Fired in humid hydrogen $\left(T_{\text {dew }} \sim 15^{\circ} \mathrm{C}\right.$, material 5$)$.

spreads out in the bulk of the grains, indicates that the apparent stability of the $\mathrm{CaO}$-free materials at $900^{\circ} \mathrm{C}$ only results from problems in initiating the reaction in the absence of $\mathrm{CaO}$ (or other substances). The experiment at $1000^{\circ} \mathrm{C}$ using the same material indicates that at this temperature initiation is no longer a problem, and the presence of calcia is no longer a prerequisite for corrosion to occur. However, adding calcia still promotes corrosion at $1000^{\circ} \mathrm{C}$ because of more rapid diffusion of sodium along the grain boundaries.

From these experiments it is clear that the addition of $\mathrm{CaO}$ should be omitted in order to obtain optimal corrosion resistance.

\subsection{Translucent alumina: effect of sintering conditions and $\mathrm{MgO}$ dope}

To study the effect of sintering atmosphere on stability, the corrosion resistance of material 1 was compared with that of material 5 sintered from the same starting powder, again containing $100 \mathrm{wt}$ ppm $\mathrm{MgO}$, using the same sintering procedure except for the atmosphere, which was humid hydrogen instead of vacuum. This sample was again heated in contact with sodium for $300 \mathrm{~h}$ at $900^{\circ} \mathrm{C}$ (Fig. 4).

In contrast with the material sintered in vacuum, the hydrogen-sintered sample clearly became corroded. Although the material did not contain appreciable amounts of $\mathrm{CaO}$, corrosion was again initiated at the grain boundaries. Sodium penetration along grain boundaries extended to at least $60 \mu \mathrm{m}$ below the surface, whereas most grains in the outer layer of the sample corroded only par- tially. Apparently, sintering in humid hydrogen leaves the grain boundaries in a more reactive state than sintering in vacuum. It should be noted, however, that the final $\mathrm{MgO}$ content of both samples after sintering might be somewhat different. Sintering in vacuum reduced the $\mathrm{MgO}$ content from 100 to $92 \mathrm{wt} \mathrm{ppm} \mathrm{[12]} \mathrm{and} \mathrm{this} \mathrm{reduction}$ is expected to be less in the case of humid hydrogen.

The effect of changing the $\mathrm{MgO}$ concentration was studied, keeping the $\mathrm{CaO}$ concentration as low as possible ( $\sim 2 \mathrm{wt} \mathrm{ppm).} \mathrm{Four} \mathrm{materials} \mathrm{(5} \mathrm{to} 8)$ were studied containing 100 (materials 5 and 6) and 300 (materials 7 and 8) wt ppm MgO, respectively, and using two sintering conditions, i.e. sintering at $1825^{\circ} \mathrm{C}$ (materials 5 and 7 ) and $1670^{\circ} \mathrm{C}$ (materials 6 and 8 ) both in humid hydrogen atmosphere.

All four examples were heated for $300 \mathrm{~h}$ at $900^{\circ} \mathrm{C}$ in contact with sodium. Materials 5 and 6 with the lower $\mathrm{MgO}$ content $(\sim 100 \mathrm{wt} \mathrm{ppm})$ proved to be far more resistant than materials 7 and 8 with the higher MgO content $(\sim 300 \mathrm{wt}$ ppm). In its turn, material 6 sintered at $1670^{\circ} \mathrm{C}$ proved to be more resistant than material 5 sintered at $1825^{\circ} \mathrm{C}$, but still less resistant than the material sintered in vacuum at $1825^{\circ} \mathrm{C}$, i.e. mat. erial 1. The $300 \mathrm{wt} \mathrm{ppm} \mathrm{MgO}$ materials (materials 7 and 8) suffered from severe corrosion. The outer millimetre of these samples was converted almost completely into NA, and sodium pentrated the grain boundaries throughout the samples $(\sim 4 x$ $4 \times 4 \mathrm{~mm}^{3}$ ). All four samples considered clearly suffered from sodium penetration along grain boundaries. 
These experiments show that, irrespective of sintering temperature, the corrosion resistance of $\mathrm{H}_{2}$-sintered alumina drops drastically if the $\mathrm{MgO}$ content of the sinter powder is raised from 100 to $300 \mathrm{wt}$ ppm. Furthermore, sintering at $1670^{\circ} \mathrm{C}$ resulted in at least as resistant materials as $\sin ^{\text {. }}$ tering at $1825^{\circ} \mathrm{C}$.

\section{Conclusion}

On thermodynamic grounds it is predicted that $\mathrm{Al}_{2} \mathrm{O}_{3}$ is not stable in contact with sodium. This prediction has been confirmed by corrosion experts on sapphire and (polycrystalline) alumina at temperatures ranging from 800 to $1000^{\circ} \mathrm{C}$. In this temperature regime, $\mathrm{Na}_{2} \mathrm{O} \cdot \mathrm{Al}_{2} \mathrm{O}_{3}$ was the only detectable corrosion product. Sapphire samples showed a large anisotropy in their corrosion resistance, the basal plane being considerably less attacked than the prism-like plane. This anisotropy plays a minor role in polycrystalline alumina because in that material grain-boundary penetration dominates. For polycrystalline alumina it is concluded from corrosion experiments on ceramics sintered in hydrogen that the addition of $100 \mathrm{wt}$ ppm $\mathrm{MgO}$ results in more resistant materials than the addition of $300 \mathrm{wt}$ ppm MgO. A slightly better relative corrosion resistance is obtained after sintering at $1670^{\circ} \mathrm{C}$ than after sintering at $1825^{\circ} \mathrm{C}$. A much better corrosion resistance is obtained by firing in vacuum; in particular, grain-boundary penetration is significantly less. On the other hand, the addition of $\mathrm{CaO}$, which is done to increase the optical transmittance, is detrimental to the corrosion resistance. Since it has been shown that $\mathrm{CaO}$ also has a harmful influence on the mechanical properties of alumina [12], the addition of $\mathrm{CaO}$ should be avoided.

\section{Acknowledgement}

Grateful acknowledgements are due to E. Groenewoud for the electron microscope analysis and to C. Langereis for the $\mathrm{X}$-ray analysis.

\section{References}

1. B. J. HUNTING and G. A. JEUNINK, US Patent 3846146 (1973).

2. BP 1252851 (1969).

3. P. E. C. FRANKEN and A. P. GEHRING, J. Mater. Sci. 16 (1981) 384.

4. E. WYNER, J. Iluminating Eng. Soc. 8 (1979) 166.

5. P. HING, ibid. 10 (1981) 194.

6. P. R. PRUD'HOMME VAN REINE, Sci. Ceram. 12 (1984) 741 .

7. N. A. TOROPOV, "Handbook of Phase Diagrams of Silicate Systems", Vol. 1 (Israel Programme for Science, Jerusalem, 1972).

8. R. G. DE VRIES and W. L. ROTH, J. Amer. Ceram. Soc. 52 (1969) 367.

9. D. R. STULL and H. PROPHET, "JANAF Thermochemical Tables", NSRDS-NBS 37, 2nd edition (US Department of Commerce, Washington, 1971).

10. J. T. KUMMER, Progr. Solid State Chem. 7 (1972) 141.

11. I. BARIN, O. KNACKE and O. KUBASCHEWSKI, "Thermochemical Properties of Inorganic Substances" (Springer Verlag, Berlin, 1977).

12. G. DE WITH, I. Mater. Sci. 19 (1984) 2195.

13. J. G. J. PEELEN, Thesis, University of Technology, Eindhoven (1977).

14. H. E. EXNER, Int. Metall. Rev. 17 (1972) 25.

15. D. PROKIC, J. Phys, D. Appl. Phys. 7 (1974) 1873.

Received 30 April

and accepted 23 May 1984 